\title{
Cognitive Processes on Translation Studies of English Language Learners
}

\author{
$\underline{\text { Anni Holila Pulungan }}{ }^{1}$, Masitowarni Siregar ${ }^{1}$, Rahmad Husein $^{1}$, Nora Ronita Dewi $^{1}$ \\ ${ }^{1}$ Universitas Negeri Medan, Indonesia \\ Email: anniholilapulungan@gmail.com
}

\begin{abstract}
There were many studies discussed on the product of translation. Meanwhile, few researcher lazy to watch the process of translation. This paper, therefore, investigated a study on the processes when a translator performed the translation. The cognitive process played an important role in it. The aims of the study are to describe the think aloud protocols as one of the assessment to explore the translation behaviours or strategies in translation and to analyze cognitive processes that occur in the mind of postgraduate students when they did the translation. This research is also necessary to know the difficulties faced by the students when conducting the process of it. The study that involved fifteen participants, resulted to some difficulties, namely in translating lingual word unit, lingual phrase unit, and lingual clause unit. The overcome strategies were refers to a dictionary, knowledge of the subject (guessing), and the attention of local context and content. It is suggested that, although the think-aloud assessment has limitations, but it is an appropriate instrument for looking into the mental process of a translator.
\end{abstract}

Keywords: translation; think aloud protocol; cognitive process

\section{Introduction}

Translation study in Indonesia is still underdeveloped repercussions. And if there is any, is only a product of translation studies (product), teaching translation techniques, evaluation and assessment of the development of translation. According to Munday (2001: 4-5), 'product' is the text that has been translated, while 'process' is the activity of producing a translation. Aly (1990) designed a learning material in the translation for the English education students in the English department. Gabr (2002) conducted a study on the behavior of the program students S1 translation. Meanwhile, El-Sakran (2002) examined the issue of gender in the translation from English into Arabic. Other researchers who also conducted research on the translation of the translation products was El-Sheikh (1987) suggests a communicative approach to teaching translation to help students in developing capabilities in a systematic way. Al-Maghraby (1995) developed a translation guide based on the needs of students and used communicatively in the target language.

On the one hand, there were not many researchers who conduct research on the process of translation. Lorscher (1991), for example, found the difficulties that occur in the process of translating the syntactic and lexical. At least the researchers who undertook the study of this process, because many factors related that arise when a translator perform the translation process. Cognitive and mental processes that occur must be observed in detail so as to make researchers lazy to watch. It can be also analogous to when an architect designing a building. At the time of the architectural design of a building there are many elements involved such as cognitive processes, the use of knowledge and implementation of strategies to build a nice building. It's liked a translator. When a translator performed the translation, the cognitive process played a role in it. When a person's cognitive process better it will be good also of the translations. However, otherwise the result is not good. Knowledge is one of the elements that must be owned by a translator. With its knowledge of the translator will determine the appropriateness of the translation. 
This study observed the cognitive processes that occur in the mind of a translator when he did the translation. This research is also necessary to take the acquisition of outcomes research which expected as forms of cognitive processes contained in translators when doing the translation process, the difficulties faced by a translator when conducting the process of translation, the translator strategy undertaken in overcoming the problems when the translation process is underway, and the appropriate teaching models for improving the translation capabilities of students.

\section{Review of Literature}

\subsection{Translation Process}

Translation is the meaning transfer activity from a source language text (SL) language text into the target language (TL). If the language was only a series of concepts that are common or universal then it will be very easy to translate from the source language to the target language. However, in reality many things that must be considered in the process of translation. Translation goal is to produce the kinds of text-such as religious texts, literature, science, and philosophy-text in another language and give it to the reader. In the translation of many elements that must be considered such as the lexicon of a language, grammatical structure, communication situation, cultural context, and their own knowledge, so it can produce a product of Appropriate translation with the target text.

When a translator do the translation of the texts, the translator is conducting a series of cognitive processes such as analyzing, interpreting, forming new formats of the messages contained in a text and transfer of the source language to the target language as shown in figure (1) this below.

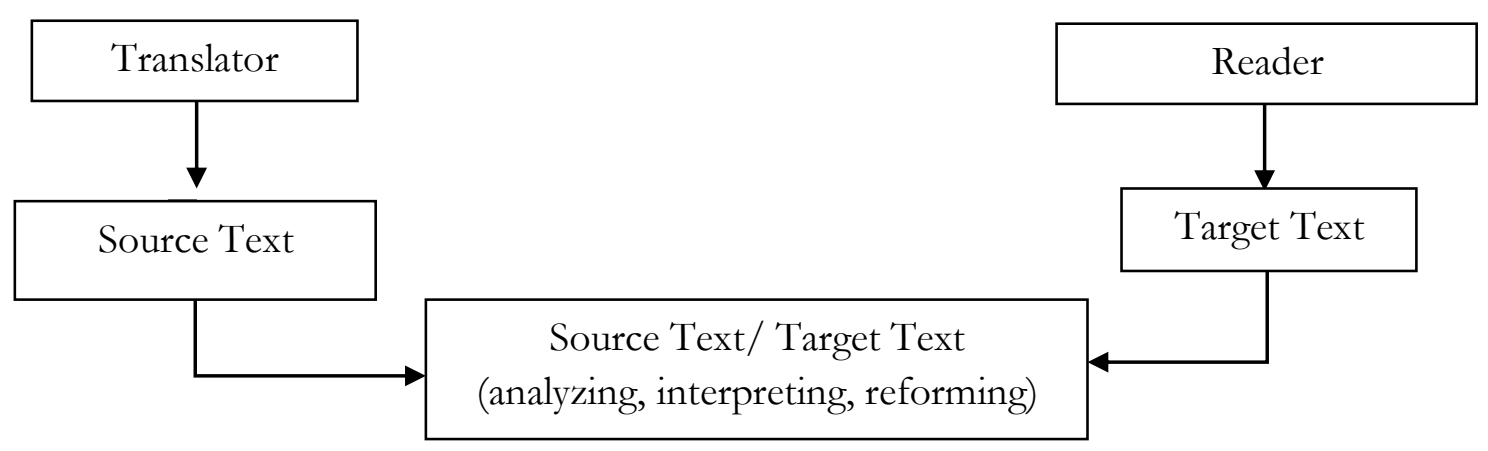

Figure 1. Basic Concepts Translation

The differences between the source language and the target language and the variety of cultures between the two languages make the translation process an interesting challenge. This study looks at the extent to which translator's knowledge and culture affect the translation process.

\subsection{Think Aloud Protocols Method}

Think Aloud Protocol (TAP) is a direct method that observes in depth the process of knowledge or problems that exist when someone solves a problem. Van Someren et. al. (1994: 12) said that TAP method is usually used to find out more about cognitive processes. This method also showed in detail how someone solved the problem step by step. Van Someren, said that,

"This method consist of: (a) collecting think aloud protocols by instructing people to colve one or more problems while saying "what goes through their head", stating directly what they think. (b) 


\section{analyzing the protocols to obtain a model of the cognitive processes that take place during the problem solving.}

Furthermore, Toury (1991: 95) asserted that the subjects involved in the translation process required to saying speech that is present in their minds when they're on the move. Their whole speeches were recorded, transcribed and analyzed.

Furthermore, TAP method is a method that involves students to tell their thoughts while searching for strategies to understand the text they are translating. Steinkuehler and Derry (2001) suggest:

a) Do not involve students in social interaction when the process of translation. When they stop said their mind, tell the student to continue said, do not stop.

b) Do not panic when the students' speeches were found not coherent or less coherent from one sentence to the next sentence.

c)Do not use this method to something that is visual.

d) Ensure the translation process takes place with the best.

This method has been widely used for various solutions in the learning process. However, in Indonesia this method was rarely used. Hence, this study is used TAP method.

\subsection{Think Aloud Protocols and Translation Process}

In recent years, Think Aloud Protocols method is used in the new translation process research. Translation is a highly complex cognitive activity and also an activity that requires troubleshooting. Therefore, many experts in the translation are starting to use this method.

Studies on the translation either in the form of teaching studies associated with the translation, evaluation and assessment process of translation, materials translation, already started using this method. Similarly, this study is assessed by the method of Think Aloud Protocols.

\section{Research Methods}

This translation study is a qualitative descriptive study. Research on this translation method utterances Think Aloud Protocols (TAP). The data source is taken from ten students of English Applied Linguistics Program at Universitas Negeri Medan. The ten students are students who have completed the courses of Translation Studies I and Translation Studies II. Meanwhile, the provision of data is sampled from Semantic books, Research books, and Engineering books. The complete source of the three texts can be seen in Table 1.

Table 1. List of Texts Used for Provision of Data

\begin{tabular}{llll}
\hline No. & $\begin{array}{l}\text { Text } \\
\text { Code }\end{array}$ & $\begin{array}{l}\text { Number } \\
\text { of words }\end{array}$ & Sources \\
\hline 1 & SM & 300 & $\begin{array}{l}\text { Platt, Mark deBretton. 1997. Ways of Meaning: An Introduction } \\
\text { toPhilosophy of Language. Mass:MIT Press. Page. 68 }\end{array}$ \\
2 & TBI & 264 & $\begin{array}{l}\text { Auerbach, Carl F dan Louise B Silverstein. 2003. Qualitative } \\
\text { Data: An Introduction to Coding and Analyisis. New York:NYU } \\
\text { Press. Page. 31-32 } \\
\end{array}$ \\
3 & TK & 241 & $\begin{array}{l}\text { Marghibu, Dan B. 2001. Mechanical Engineer's Handbook. } \\
\text { NY:Academic Press. Page. 46. }\end{array}$ \\
\hline
\end{tabular}




\section{Discussion}

\subsection{Types of Difficulties in Translation}

The result showed that in general the difficulties faced by the subject when translating can be grouped into three major groups, namely, the difficulties experienced by subjects in translating lingual word unit, lingual phrase unit, lingual clause unit, and groups in translating the sentence lingual unit.

The difficulty in translating lingual units of words is divided into four problems. First, the subject does not know the meaning of the word to be translated. This can happen because the subject has just found the word for the first time or has known its meaning but at that time forgot the meaning or doubt the meaning. This can be known when the subject in his mind asks the meaning of the word when translating or directly looking for it in a dictionary as in (1).

(1) a.apa sib sebenarnya artinya doctrine? (SMP-RK)

(what is the meaning doctrine?)

b. di kamus arti enduring termyata 'kronis'. (SM-FDL)

(in the dictionary the meaning of enduring turns out to be 'chronic')

c. di awal pengerjaan sudab bingung karena beberapa kata unfamiliar. (TK-IK)

(at the beginning of the work was confused because some unfamiliar words).

The most unknown words from the subject come from TK texts. This can be understood because the TK text is a text taken from a technical book. Some of these included words such as 'friction force', 'equilibrium balance', and 'inclined plane'. Next are the words that come from BC text. Although the problems associated with the SM text semantics, the content of the text is more to the philosophical discussion. That is why even though the semantics are relatively well known by the subject, there are a number of words that are not known as 'a priori', 'Prototractatus' (titles), and 'consequentialist'. Meanwhile, the unknown words in the TBI text is less relative, because of the subject is generally recognized TBI which related to the research.

Secondly, the difficulty in translating lingual word unit is known of doubt subject to the equivalent word that he knows when translating. Doubts arose because he knew equivalent word is not in accordance with the context. Doubt it can be seen from the results of the data analysis (2).

(2)a. course di sini artinya apa ya? Nggak mungkin 'kursus', kan nggak bercerita tentang kursus. (SM-MJ)

(course what does that mean here? There's no way 'course', it's not about the course).

b. Now the fun starts. 'Kesenangan dimulai' cocok apa nggak ya? Atau memulai sesuatu dengan perasaan senang atau bahagia kali. (TBI-SEB)

(Now the fun starts. 'Fun starts' does it match or not? Or start something with a happy feeling or happy times).

Data (2) shows that the subject knows the equivalent of the word to be used but, the subject is hesitant to use the equivalent of the word he already knows. The doubt is caused if the equivalent of the word he knows is used, the word does not fit the context or the word does not produce a sentence that makes sense according to him. What is interesting is that the process results in a better translation as shown in the data (2). At least, the subject realizes that the equivalent of the word he has is not appropriate for the text he is translating. The results of this 
analysis also show-also reinforce various explanations in various translation theories-that context knowledge helps translators translate a text.

The third difficulty is difficulty that is not realized by the subject when translating. The difficulty is seen from the mistake or inaccuracy of the subject in translating a word contained in the text. This can be seen from how the subject's cognitive process when doing translation. Difficulties in the form of inaccurate use of the word equivalent can be seen in the data (3)-(4).

Data (3) is an example of the inappropriateness of the use of equivalent word used by the subject to the word "suggest" in a sentence 'The term coding can be misleading; it suggest a routine mechanical process'.

(3) a. Istilab "coding" atau "pengkodean" bisa saja membuat salab pengertian yang menyarankan proses mekanisme rutin. (TBI-IS)

(The term "coding" or "encoding" could create misunderstanding that suggest the routine mechanism)

b. Istilah kode dapat disalah-artikan, kode menyarankan mekanisme proses yang rutin. (TBI-EAS).

(The term code may be "misinterpreted", the code suggests routine process mechanism)

c. Istilah kode dapat menyesatkan; hal tersebut menyarankan sebuah proses mekanik rutin. (TBI-CL)

(The term code may be misleading; it suggests a routine mechanical process).

In general, subjects know the word 'suggest' in Indonesian as an equivalent word to suggest in English. In fact the word to suggest in the sense of 'suggest' which is indeed often used in various English texts both oral and written. However, in English, besides meaning and synonym with the word to advise or to recommend, the word to suggest can also mean and be synonymous with the word to imply or to indicate. Therefore, the use of the word 'suggest' to translate the word suggest in the sentence is not appropriate. The word suggest in the sentence would be more correct if translated with 'implies' or more informally by 'giving an impression'. Better complete translations can be seen in (3.d) and (3.e).

d. Istilah pengkodean dapat disalah-artikan; istilah tersebut mengimplikasikan sebuah proses mekanis rutin.

(The term coding can be misunderstood; the term implies a routine mechanical process).

e. Istilah pengkodean dapat membuat salah pengertian; istilah tersebut memberi kesan sebuah proses mekanis rutin.

(The term coding can make any sense; The term gives the impression of a routine mechanical process).

Data (4) is an example of inaccurate use of the word used by the subject for the word a priori in the First sentence, there is the view that the analysis of meanings can be a priori procedure.

(4) a. Pertama, ada pandangan bahwa analisa arti dapat menjadi sebuah prosedur yang utama (SM-SUE)

(First, there is the view that analysis of the meaning can be a major procedure)

b. Pertama, ada pandangan bahwa analisis makna dapat menjadi sebuah prosedur utama (SM-RAA)

(First, there is the view that analysis of the meaning can be a major procedure). 
c. Pertama, ada pandangan bahwa analisis dari arti dapat dijadikan sebuah prioritas dan prosedur (SM-RP).

First, there is the view that analysis of the meaning can be made a priority and procedures).

In general, the subject considers the equivalent word a priori as 'main' or 'priority'. It seems that the subject's beliefs were triggered by the similarity between the word a priori and the word 'priority'. There is one subject who doubts the relationship between the two because of the article (article) 'a' in the word a priori while in front of it there is also another article, 'an'. However, the cognitive process of the subject says "why are there two articles in that statement? Maybe it's a typo ... But in the dictionary there is only the word prior without article a ... ".

The results of this data analysis show that in essence the whole subject did not recognize the word a priori which in Indonesian is generally written with the same word. The word a priori is a term in philosophy - including the philosophy of science - that deals with issues of fact and empirical observation. In fact, the text itself actually has provided an explanation of what is meant by a priori in the text as shown in (5).

(5)'Pertama, ada sebuah pendapat yang menyatakan bahwa analisis makna merupakan sebuah prosedur a priori: kebenaran-kebenaran yang terdapat pada makna dapat diketahui tanpa melalui pengamatan empiris'

(First, there is the view that analysis of meaning can be an a priori procedure: truths about meanings..... can be known without recourse to empirical observation).

The text "truths about meanings ...... can be known without recourse to empirical observation" is an explanation of what is meant by a priori procedure in the previous sentence. The results of this analysis-as mentioned briefly earlier-also show how context knowledge greatly influences the results of good translations.

The last difficulty is the difficulty experienced by the subject when translating pronouns. Although in the process of translation they feel no difficulty translating pronouns, the results of the translation show that pronouns include lingual units of words that are difficult to translate. For example is data (6) which is a translation of the pronoun in the sentence "The term coding can be misleading; it suggests a routine mechanical process. "

(6) a. Istilah "coding" atau "pengkodean" bisa saja membuat salah pengertian yang menyarankan proses mekanisme rutin. (TBI-IS)

(The term "coding" or "encoding" could create misunderstanding that suggest the routine mechanism process).

b. Istilah pengkodean dapat menyesatkan; ini menunjukkan sebuah proses mekanisme rutin. (TBI DA)

(The term coding can be "misleading"; this shows a routine mechanism process).

It appears that the translation of the pronouns is incorrect and feels unnatural in the Indonesian language, as well as producing false meanings. The use of reflexive pronouns in (6.a) results in meaning errors. It is misunderstanding that suggests a routine mechanism process. Meanwhile, this reference to (6.b) is also incorrect because it does not clearly refer to which lingual unit. In general, Indonesian requires repetition as a cohesion tool rather than a pronoun. Therefore, a more natural translation in Indonesian is as in (7). 
(7)a. Istilah pengkodean dapat membuat salah pengertian; karena istilah pengkodean memberi kesan sebuah proses mekanis rutin.

(The term coding can make any sense; because the term encoding gives the impression of a routine mechanical process).

b. Istilah pengkodean dapat membuat salah pengertian; karena istilah tersebut memberi kesan sebuah proses mekanis rutin.

(The term coding can make any sense; as that term gives the impression of a routine mechanical process).

Those are the four difficulties encountered by the research subjects when translating lingual units of words. Judging from the cognitive processes of the subjects when translating, the difficulties they experience can be (i) difficulties they are aware of and (ii) difficulties that they are not aware of. Meanwhile, judging from the types of difficulties they experienced, difficulties in translating can be grouped into three. First is the difficulty caused by the lack of vocabulary in English so that they do not know the meaning of a word or doubt the meaning they already know. Second is the difficulty caused by the lack of Indonesian vocabulary so that it cannot offer words that are more appropriate in the context. Finally, difficulties in producing cohesive and natural translations in Indonesian.

\subsection{Difficulties in Translating Phrases Lingual Unit}

The difficulty in translating lingual units of phrases shown by research subjects is divided into three problems. First, the subject faces the problem of which sequences are core words and which modifiers translate phrases. Meanwhile, analysis of the results of the translation which shows the subject faces difficulties in translating the lingual unit sequence of phrases such as "a loosely ruminative and comparative-historical remark" can be seen in the data (8).

(8) a. Sebuah peninggalan sejarah yang komparatif dan kurang direnungkan (SM-MJ)

(A comparative and less contemplated historical heritage).

b. Sisa-sisa peninggalan sejarah yang ruminative dan ...... (SM-RK)

(Ruminative and historical remains).

All research subjects had difficulty in translating the phrase "a loosely ruminative and comparative-historical-remark". In general, the difficulty is seen in the deficiencies in observing the order of the core constituents and modifiers. The core constituents of the phrase are clearly the words remark which in the text would be more correct if translated as 'observation'. Meanwhile, the modifier consists of two, namely (i) ruminative and (ii) comparative-historical; while the word loosely can be understood ambiguously whether to be a modifier of ruminative words or for both ruminative and comparative-historical. The safest way to avoid the ambiguity contained in the phrase is to apply the mirror method in translating the phrase. Even if the subject does not know the meaning of each word contained in the phrase, the formal results of the translation are not wrong in terms of the order in which the core constituents and modifiers are as shown in (9).

(9) a. $\frac{\text { loosely }}{1} \frac{\text { ruminative }}{2} \frac{\text { and }}{3} \frac{\text { comparative-historical }}{4} \frac{\text { remark }}{5} \quad 6$

b. pengamatan historis-komparatif dan ruminatif secara longgar.

$\begin{array}{llllll}6 & 5 & 4 & 3 & 2 & 1\end{array}$

c. pengamatan historis-komparatif dan kontemplatif yang dilakukan secara longgar 
The translation result (9.c) places the loosely modifier 'loosely' as the original as a direct modifier of the 'contemplative' ruminative word. The ambiguity of the loosely modifier 'loosely' remains as the original, which can only be a modifier of the word 'contemplative' or both 'historical-comparative and contemplative'. However, the most appropriate possibility, based on the text as a whole, is that the word loosely 'loosely' is a modifier for 'historical-comparative and contemplative'. So, what is done loosely is its historical-comparative observation and also its contemplative observation.

Examples of data difficulties in translating word sequences in other phrases are contacting surfaces. The core constituents of the phrase are the word surfaces 'surfaces'. The translation of the phrase, therefore, is 'confusing/touching surfaces'. The core constituents of the translation phrases are the word 'surface'.

Another difficulty experienced by the subject in translating phrases relates to phrases in which there are ellipsis or fissures such as the fathering role as strained and conflictual. The word that is dissolved in the phrase is the word role 'role' in the as strained and conflictual role. Because the subject does not understand the word being blown away, the results of the subject's translation become less or less natural as shown in the data (10).

(10) a. peran fathering tegang dan penub konflik. (TBI-DA) (peran fathering tense and full of conflict)

b. sebagai ayah yang tegang dan memiliki masalab (TBI-BNAL) (as a father who is tense and has problems)

c. peran ayah sebagai konflike (TBI-FZ)

(father's role as conflict)

The difficulties experienced by the subject generally indicate how the subject still has weaknesses in analyzing the phrases in detail. The phrase fathering role is a phrase that consists of two very familiar words, namely (i) father and (ii) role. The word role is its core constituent and, therefore, the word father is its modifier. The addition of the suffix -ing to the word father reinforces it as a modifier in the phrase fathering role. The additional -ing suffix itself indicates the process of becoming, so that the phrase fathering role would be more correct if translated 'role to be father'. Overall, the translation of the phrase the fathering role as strained and conflictual is 'the role of being/as a father as the role of the role that is full of burden and conflict'. In the Indonesian language, the word role that is being sown must be re-raised and cannot be sited as in English.

Slightly different from the difficulties faced by the subject in translating words, the difficulties in translating phrases are generally not explicitly recognized by the subject as phrase difficulties. These difficulties are analyzed based on the results of the subject's translation of the three short texts given to them. In general, the results of the analysis conducted on the subject's cognitive process when translating shows that the subject feels no difficulty in translating the phrase specifically. The problem of difficulty translating phrases in general is cognitively the problem of translating lingual units of words. The analysis of cognitive processes they convey in general provides information on general difficulties such as data (11).

(11) a. O.... Tuhan, sulit sekali menerjemabkannya... Teksnya nggak familiar buatku (TK-DKA)

(Subject said it is difficult to translate whether they only translate two sentences of TK text. The difficulty is caused by the unfamiliar himself to TK text.)

b. Sepertinya teks ini lebih susah menerjemahkannya yang pas (SM-RS) 
(Subject compared that SM text feels more difficult than the text he translated before, that is TBI text. Even so, the cognitive process that is informed by the subject showed that translating the TBI text in general is also difficult for him.)

Thus, it can be said that the inaccuracies and mistakes made by the subjects in translating the texts provided are a result of the difficulties they face in (i) translating words and (ii) translating the intent of the texts.

\subsection{Difficulties in Translating Lingual Units of Clause}

The results of data analysis show that the difficulties experienced by subjects in translating clauses arise when they translate multilevel compound clauses whose relative pronouns are neglected. For example, the sentence $\mathrm{N}$ is the normal force exerted by the surface in the TK text. The sentence basically consists of two sentences as mentioned in (12.a) and (12.b). Meanwhile, compound sentences derived from the two sentences can be seen in (12.c).

(12) a. $N$ is the normal force

b. This normal force is exerted by the surface

c. $N$ is the normal force which is exerted by the surface

The English rule allows the relative pronouns of which and auxiliary verbs to be blown from sentence (12.c) to $\mathrm{N}$ is the normal force exerted by the surface. However, the rules of the Indonesian language do not allow for that. Therefore, the relative pronoun 'yang' 'which' must appear in Indonesian becomes ' $\mathrm{N}$ is the normal force exerted by the surface of a plane'.

\subsection{Strategies Used in Overcoming Difficulties}

The results of data analysis show, as explained in the previous section, that there are essentially two types of difficulties experienced by the subject when translating a text. The first difficulty is the difficulty that they are not aware of and the second difficulty is the difficulty that they are aware of. The first difficulty results in a number of inaccuracies and errors made by the subject in translating lingual units of words, phrases, and clauses. The results of the analysis and discussion have been presented descriptively in the previous section and again will be explored explosively in the next section. Meanwhile, the second difficulty gave birth to a strategy carried out by the subject to overcome the difficulties being faced in translating.

The results of data analysis show that there are three strategies used by the subject when facing difficulties in translating. The first and easiest strategy is to refer to the dictionary as shown in the data (13).

(13) a. mencari arti yang cocok untuk kata course di kamus (SM-MJ)

(look for a suitable meaning for the word course in the dictionary)

b. shades? Apa ya? Coba cari dulu di kamus (SM-RK)

(shades? What is it? Try searching first in the dictionary)

c. banyak kata yang sulit, harus buka kamus dan siapkan tip-ex (TK-CL)

(many difficult words, must open the dictionary and prepare tip-ex).

It can be said that in general the subject will refer to the dictionary if they have difficulty in translating a word. This is the most common strategy and is easy to implement when translating. 
However, just referring to the dictionary sometimes doesn't help. This can be seen when the subject faces the word a priori as discussed in the previous section. When the dictionary also can not provide a way out, the next strategy used by the subject is to use their existing knowledge and is related to the lingual unit they are dealing with. For example is the word a priori in the SM text. They stated that they did not get it in the dictionary. For this reason, they use their existing knowledge, for example, by understanding the word a priori as 'priority' because of their proximity to the word priority or as 'before' because of their closeness to the word prior.

The strategy is a 'guessing' strategy. Although they use the knowledge they have to guess lingual units that they do not know, guesses do not have high accuracy. His name guess can be wrong and can also be true. This strategy is not appropriate to be used to translate seriously and can only be used when facing an exam because of limited time and facilities such as not being able to look at the dictionary. The word a priori is an example of data on how all guesses made by the subject are incorrect. Examples of other data appear in data (14).

(14) Apa ya arti correspondingly? Sejauh yang kutahu, ada kata korespondensi yang berarti surat menyurat. Lebih baik kuterjemabkan menjadi 'berangsur-ansur'. (TK-EAS)

(What does correspondingly mean? As far as I know, there is a word of correspondence which means correspondence. I better translate it to 'gradually').

The next strategy used by the subject as shown by the results of the data analysis strategy is to consider the context. The result shows that there are two types of contextual strategy. The first is a contextual strategy locally. In this case the subject only pays attention to the immediate environment of the lingual unit that is facing. The guessing strategy essentially can also be included in the contextual strategy. In general, when the subject is doing the guessing, they pay attention to whether the translation form sentences make sense. Therefore, their guessing produced a sentence which makes sense as in the data (15) for translation 'The force $F$ is slowly Increased. As long as the body remains in equilibrium, the friction force must increase of $\mathrm{Fj}$, since it equals the force $F$.

(15) Tekanan F secara pelan meningkat. Selama benda tetap pada keseimbangannya, gaya gesek. Fj barus meningkat berangsur-angsur karena sama tekanan pada F.

(Pressure F slowly increases. As long as the object remains in balance, the frictional force $\mathrm{Fj}$ must increase gradually because of the same pressure on $\mathrm{F}$ ).

The use of "berangsur-angsur" as translation of the word "correspondingly" is reasonable and seemed appropriate for the sentence. In fact, the meaning correspondingly in the sentence means not only 'berangsur-angsur' but also in accordance with the increase of force F. A thing is said to be in equilibrium, it means the thing do not move, when the force (F) applied to it is less than or equal to the friction force $(\mathrm{Fl})$. Therefore, $(16)$ is more precise translation.

(16) Jika gaya F secara perlahan ditingkatkan. Selama benda tersebut tetap berada pada keseimbangannya, gaya gesek. Fj juga meningkat sesuai dengan peningkatan gaya F, karena gaya gesek. Fj sama dengan gaya F.

(If the force $\mathrm{F}$ is slowly increased. As long as the object remains in equilibrium, the frictional force $\mathrm{Fj}$ also increases with the increase in force $\mathrm{F}$, because the frictional force $\mathrm{Fj}$ equals the force $\mathrm{F}$ ).

This shows that the contextual guess strategy is not successful if the context in the form of the contents of the text itself is not understood as a whole. Actually, the results of data analysis 
also show that contextual strategies in the form of efforts to understand the contents of the text as a whole are also used by the subject when facing a number of difficulties in translating.

Thus, it can be said that there are generally two strategies used by subjects to overcome the difficulties they face when translating. The first strategy is to refer to the dictionary and the second strategy is the contextual strategy. Contextual strategy consists of local contextual strategy and content contextual strategy. Fill in the contextual strategy that will guide the other two strategies. Subjects in general still have shortcomings in using the content contextual strategy. For example, when the subject does not understand the word a priori and does not find it in the general dictionary, they will certainly look for the meaning in the dictionary of terms, in this case the dictionary of terms in philosophy or, they can also ask other people who are considered experts in the field.

\subsection{Forms of Cognitive Process when Translating}

The incompleteness is a consequence of the cognitive process of the subject which is merely or more oriented towards the 'completion' of the translation. The results of data analysis showed that the research subjects generally indicated that 'complete' was the main purpose of translation. This actually also happens in commercial translation works. How many commercial translation results that results can not be understood. This is because the contents of the translation are not the main objective of the subject, the subject does not make improvements as the translations they make. Although the time allocation given is limited, the subject is not given any sanctions if it does not finish translating in its entirety. This fact shows that the subject is still oriented towards 'finished'. This is evident from their statements as in data (17).

(17) a. Selesai... (TBI-EAS)

(Done....)

b. Akbirnya, terselesaikan juga terjemahan ini.. (TK-IK)

(Finally, this translation was completed ...)

c. Yes, selesai.. dapat tidur sekarang (SM-FDL)

(Yes, done ... can sleep now)

Another cognitive process that affects the translation process is the lack of focus on the text being translated. The results of data analysis show that when translating the subject's thoughts sometimes and even some often think things that are not related to the work of translating. When translating, some subjects think of other work as shown in the sample data (18).

(18) a. Wah.. bagaimana nanti ya jemput anak dari sekolah (SM-SUE)

(Wow ... how will you pick up the child from school)

b. Kenapa mereka dari kemarin absen kuliah dan nggak ada kabar (TBI-PRP)

(Why were they absent yesterday from college and there was no news)

Cognitive processes such as sample data (17) and (18) are cognitive processes that interfere with the translation process. In other words, it can be said that cognitive processes that can interfere with the translation process consist of two. First is a cognitive process that is oriented to "finish" and second is a cognitive process that is not focused on translation. The first can interfere with the overall quality of the translation, while the second only disturbs the wrinkling of the translation process. However, if the second confounding cognitive process is often present, it will also affect the overall quality of the translation. 


\section{Conclusion}

The deficiencies found in the translation of research subjects as explained in the previous section show that in general the research subjects still need a lot of practice in translating. These deficiencies are good in translating word lingual units, phrase lingual units, and clause lingual units.

The deficiencies contained in their translation are essentially derived from two interrelated things. First, the background knowledge possessed by the subject about the translated text is still lacking. Moreover, the subject is only oriented towards completion of the translation so that efforts to implement local contextual strategies and content appear to be minimal. Second, the subject's attention to the text being translated is not well focused. This is caused by the orientation of the subject to 'completion' and lack of background knowledge.

\section{References}

Aly, Mahsoub Abdul Sadeq. (1990). A Suggested Course in Translation for the Students of English Language Sections in Faculties of Education in Egypt. Unpublished Ph.D Thesis, Faculty of Education, Benha.

El-Sheikh, Ahmed Abdel-Azeem. (1987). A Register Approach to the Teaching of Translation. Proceeding of the $7^{\text {th }}$ National Symposium of English Teaching in Egypt, March 24-26, entitled: "Appropriate Methodologies". Cairo: CEDLT, Ain Sam University.

El-Sakran, Tharwat. (2002). Textual, Contextual, and Extra-Contextual Considration for Gender Identification in Translation. A Paper Presented at the $22^{\text {nd }}$ CEDLT National Symposium of English Teaching in Egypt, March 22-24, entitled: "The specific Role of EFL for the Arab World: The Decade Ahead". Cairo: CEDLT. Ain Shams University.

Gabr, Moustofa. (2002). Teaching Translation in Egytptian University. Translation Journal, Vol.6 No.1.

Lorscher, Wolfgang. (1991). Translation Performance, Translation Process, translation Strategies: A Physcholinguistics Investigation. Tubingen, Germany: Gunter Narr Verlag.

Munday, Jeremy. (2001). Introducing Translation Studies. London: Routledge.

Steinkuehler, Constrance A. and Derry, Sharon J. (2001). Strategies for Assessing Learning Effectiveness. Web site http://www.alnresearch. org/html/assessment/tutorial.

Van Someren, Maarten W. et.al. (1994). The Think. Aloud Method: A Practical Guide to Modelling Cognitive Processes. London: Hartcourt Brace \& Company. 